Unanimously, the respondents pointed to the extraordinary importance and relevance of the formation of foreign language competence, which helped them to adapt as quickly as possible to the difficult conditions of service abroad and to establish communication with foreign colleagues. Communication skills are among the key features of a competent communicant officer, since the main task of all commanders, staff officers and bosses is to make sure that people (officers) correctly perform their tasks and commands. importance of foreign language training was confirmed by $90 \%$ of respondents. The results of the survey showed that it is the interactive teaching methods that can make significant adjustments to the effectiveness of mastering learning material in foreign language, speeding up learning of words and terminology, developing skills of speaking and listening, and studying the cultural features of verbal and non-verbal communication.

Keywords: future officers, readiness, development, foreign language competence, interaction, role-playing teaching.

DOI: https://doi.org/10.31392/NZ-npu-143.2019.10

УДК 378.011.3-051:37.016:621.3+621.38]:377

ORCID 0000-0003-0968-1060

Дідик А. 0.

\title{
РЕАЛІЗАЦІЯ МІЖДИСЦИПЛІНАРНИХ ЗВ'ЯЗКІВ У ПРОЦЕСІ НАВЧАННЯ ЕЛЕКТРОТЕХНІКИ ТА ЕЛЕКТРОНІКИ
}

Проблема реалізації міждисииплінарних зв'язків у процесі вивчення електротехніки $i$ електроніки не втратила свою актуальність і нині. Це одне з найбільш складних методичних завдань викладача, де він повинен сконщентрувати знання з інших дисциплін, поєднавщи їх у иілісну систему.

У статті теоретично обтрунтовано реалізацію міждисииплінарних зв'язків при викладанні електротехніки та електроніки у ВНЗ. Визначено місие $і$ роль курсу загальної фізики, вищої математики, хімії та технічної механіки у процесі вивчення електротехніки та електроніки. Розглянуто навчальний курс “Електротехніка та електроніка”, щзо відіграє важливу роль у впровадженні міждисииплінарних зв'язків, які спрямовані на розв'язання нестандартних рімень на сучасному етапі розвитку суспільства. Електротехніка та електроніка, синтезуючи навколо себе інші дисиипліни, створюють величезний міждисциплінарний потенціал, внаслідок чого діяльність викладача стає більш результативною, успішною, професійною. Конкретизовано навчальні теми ичих курсів, на базі яких основані вивчення електротехніки та електроніки. Продемонстровано шляхи корегування навчальної програми із врахуванням змісту иих курсів, щзо усуває дублювання та повтори.

Установлення міждисииплінарних зв'язків між викладанням курсу електротехніки, електроніки, фізики, хімії, технічної механіки, вищої математики сприяє більш поглибленому засвоєнню знань, наукових понять $і$ законів, вдосконаленню навчально-виховного процесу та оптимальної його організації, формуванню наукового світогляду, єдності матеріального світу, взаємозв'язку явищ у природі й суспільстві. Реалізація міждисииплінарних зв'язків усуває дублювання у вивченні матеріалу, заощаджує час і створює сприятливі умови для формування фахових компетентностей.

Ключові слова: міждисииплінарні зв'язки, електротехніка, електроніка, фізика, хімія, математика, матеріалознавство. 
Проблема реалізації міждисциплінарних зв'язків у процесі вивчення електротехніки і електроніки не втратила свою актуальність і нині. 3 погляду філософського аналізу, який охоплює загальнопедагогічний, психологічний і методичний аспекти, міждисциплінарні зв'язки виступають як дидактична фоома загального принципу системності. Це одне з найбільш складних методичних завдань викладача, де він повинен сконцентрувати знання з інших дисциплін, поєднавши їх у цілісну систему. Пошуки ефективних шляхів розвитку навчальновиховного процесу в вищому навчальному закладі все більше привертає увагу педагогів, учених, методистів і практиків. Установлення міждисциплінарних зв'язків між викладанням курсу електротехніки, електроніки, фрізики, хімії, технічної механіки, вищої математики сприяє більш поглибленому засвоєнню знань, наукових понять і законів, вдосконаленню навчально-виховного процесу та оптимальної його організації, формуванню наукового світогляду, єдності матеріального світу, взаємозв'язку явищ у природі й суспільстві. Це підвищує науковий рівень знань студентів, розвиває логічне мислення та творчі здібності. Реалізація міждисциплінарних зв'язків усуває дублювання у вивченні матеріалу, заощаджує час і створює сприятливі умови для формування фахових компетентностей. Слід зазначити, що міждисциплінарні зв'язки слід розглядати як відображення міжнаукових зв'язків, що складають одну 3 характерних рис сучасного наукового пізнання.

Висвітлення проблем, пов'язаних з використанням міждисциплінарних зв'язків у навчальному процесі, започатковано й розвинуто в працях провідних фахівців у галузі педагогіки і дидактики. Ідея міждисциплінарних зв'язків розглядалася ще класиками педагогіки: І.Г.Песталоцці, Я. А. Коменським, І.Ф.Гербартом та ін. Результати аналізу науково-методичної літератури та періодичних видань дають можливість стверджувати, що реалізація міждисциплінарних зв'язків сприяє кращому засвоєнню природничих дисциплін та вдосконалює навчально-виховний процес у вищих закладах освіти. Міждисциплінарні зв'язки були предметом досліджень багатьох науковців, але і донині це не втратило своєї актуальності у сучасній педагогічній науці. На всіх рівнях освіти відбуваються зміни, зокрема триває процес оновлення і затвердження стандартів педагогічної освіти на основі диверсифікаційного підходу. Уніфікація системи психолого-педагогічної підготовки викладачів професійного навчання з метою підвищення ії якості передбачає міжнаукову інтеграцію засобами міждисциплінарних зв'язків [1, с.21]. Проблематика реалізації міждисциплінарних зв'язків у професійній освіті ґрунтовно представлена у дослідженнях таких відомих вчених, як Р. Гуревич, М. Корець, Н. Ничкало, В. Сидоренко, В. Стешенко, С. Ткачук, Д. Тхоржевський, О. Щербак та багатьох інших. Аналіз останніх публікацій свідчить про те, що в умовах модернізації вищої професійної освіти процес реалізації міждисциплінарних зв'язків потребує більш детального дидактичного опрацювання, особливо для дисциплін інженерно-педагогічного циклу.

Метою cmammi $є$ теоретичне обґрунтування реалізації міждисциплінарних зв'язків при викладанні електротехніки та електроніки у ВНЗ.

Однією з важливих умов усталеного фрормування навичок, які набувають 
студенти, $€$ здійснення міждисциплінарних зв'язків у процесі викладання навчальних предметів. Вирішення проблеми міждисциплінарних зв'язків відіграє важливу роль при визначенні змісту, методів і організації процесу навчання. Вислів “міждисциплінарні зв'язки” вказує на вираження фрактичних зв'язків, що встановлюються в процесі навчання або в свідомості студента між різними навчальними предметами. Незважаючи на причину багатогранного трактування поняття "міждисциплінарні зв'язки”, науковці вбачають його відображення в об'єктивно існуючому багатофрункціональному характері. Серед них у предметній системі навчання вони виділяють такі функції: методологічну, формувальну, виховну, навчальну, розвивальну, конструктивну, системно навчальну [2, с. 46]. Деякі автори дидактичних досліджень вважають, що міждисциплінарні зв'язки мають дві сторони - об'єктивну і суб'єктивну. Об'єктивна сторона міждисциплінарних зв'язків знаходить вираження у визначенні змісту навчання і враховується при розробці навчальних планів, програм, складанні підручників, навчальних і методичних посібників із відповідних навчальних дисциплін. Суб'єктивна сторона міждисциплінарних зв'язків здійснюється педагогами в процесі навчання. Оскільки міждисциплінарні зв'язки мають різноманітність дидактичних функцій, то їх класифікують за такими ознаками: за змістом навчального матеріалу; за методами та засобами навчання; за уміннями, що формуються. Міждисциплінарні зв'язки ми поділяємо на внутрішньоциклові (зв'язки елетротехніки з фрізикою, хімією) і міжциклові (зв'язки електротехніки з історією, всесвітньою літературою тощо). Використання міждисциплінарних зв'язків - одне 3 найскладніших методичних завдань педагога, бо воно вимагає додаткових знань змісту програм і підручників 3 інших дисциплін. Обсяг матеріалу, що використовується з інших дисциплін, повинен бути за можливістю невеликим [3, с. 165]. Готуючись до практичних занять, викладач повинен вирішити питання про глибину розкриття матеріалу з міждисциплінарних зв'язків у курсі електротехніки та електроніки. Сукупність функцій цих зв'язків реалізується в процесі навчання, якщо викладач використовує все розмаїття їх видів. Реалізація міждисциплінарних зв'язків на практиці передбачає співпрацю з іншими викладачами навчальних дисциплін. Аналіз проблем, які виникають при вивченні електротехніки та електроніки, показав, що базою для вивчення цих дисциплін, $є$ фрізика. Проте багато студентів не усвідомлюють значущість вивчення фрізики, у них недостатньо формуються фрізичні знання і уміння, що не дозволяють їм повною мірою орієнтуватися в технічних схемах. Студенти не вміють переносити знання, отримані при вивченні фрізики, для пояснення процесів, що вивчаються в електротехніці. Отже, тут існують резерви для підвищення якості підготовки майбутніх фрахівців, які пов'язані з практичною реалізацією міждисциплінарних зв'язків у навчальному процесі. Аналіз програм з фрізики, електротехніки та електроніки показує, що в них закладені значні можливості для здійснення міждисциплінарних зв'язків. Такі взаємодії можуть здійснюватися на основі комплексного вивчення в фізиці, електротехніці та електроніці одних і тих же фрізичних понять, явищ, величин на основі використання загальних теорій, моделей і законів. На рис. представлена схема реалізації міждисциплінарних дисциплін. Тому в процесі вивчення курсу “Електротехніка та електроніка" передбачені відповідні теми: електричне поле, 
електричні кола постійного струму, електромагнетизм, електричні вимірювальні прилади, електричні машини змінного та постійного струмів, електричні та магнітні елементи автоматики, основи електроприводу, передача і розподіл електроенергії [4, с.56]. Ключовою ланкою в розкритті даних тем, вочевидь, буде трифразна система змінного струму, що об'єднує в собі три однофазні кола, функціонування яких базується виключно на фрізичних законах. На прикладі теми "Електротехніка" можна також виділити декілька етапів формування понять: 1) магнетизм, електромагнітна індукція, постійний і змінний електричний струм, провідники і діелектрики, електричне коло, джерела і споживачі електричної енергії; 2) принцип дії простого генератора і електродвигуна, трансформація, електричний нагрівач, робота і потужність електричного струму, електричний опір; 3) пристрій сучасного генератора, трифазного трансформатора, електричні дроти тощо [5, с. 83]. Аналіз етапів формування вказаних понять показує, що успішне виконання поставленого завдання можливе лише при знанні основних законів фрізики і втілення їх в конкретні елементи устаткування. Отже, проблема раціонального розподілу дидактичних функцій двох дисциплін дасть змогу студентам швидко і якісно засвоїти навчальний матеріал при вивченні фахово спрямованого курсу “Електротехніка та електроніка". На підставі вищевикладеного стає очевидним, що реалізація міжпредметних зв'язків вказаних дисциплін може здійснюватися через: 1) коригування навчальних програм; 2) розроблення завдань, що враховують інтереси двох дисциплін; 3) видання навчальних посібників, які забезпечують плавний перехід від курсу фрізики до курсу “Електротехніка та електроніка"; 4) поєднання підсумкового і вхідного контролю з обох дисциплін.

У процесі викладання електротехніки та хімії міждисциплінарні зв'язки можуть здійснюватися в таких напрямках: формування у студентів фундаментальних понять про структуру речовини і процеси, що відбуваються в структурних елементах речовин; вивчення загальних для електротехніки і хімії законів - основні закони електролізу, хімічні джерела струму та їх застосування, класифрікація електротехнічних матеріалів: провідники, напівпровідники, діелектрики, електричні властивості речовини з погляду зонної теорії твердого тіла [6, с. 17]. Наявність міждисциплінарних зв'язків дає змогу створити в студентів уявлення про системи універсальних законів, про загальні теорії і комплексні проблеми Загальними для цих дисциплін, наприклад, є: система понять про речовину та ії̈ будову, яка необхідна для засвоєння фундаментальної електро-хімічної теорії будови речовини, система понять про енергію, ї̈ види і перетворення, зокрема поняття про внутрішню енергію, енергію активації, йонізації, поняття про молекулу і кристал тощо. Узагальнення знань студентів про кристали продовжується на заняттях з електротехніки та електроніки при вивченні напівпровідників і на заняття з хімії при вивченні алотропних видозмін вуглецю. Із змісту електроніки використовуються знання про провідники і діелектрики, про взаємодію заряджених частинок, про елементи молекулярно-кінетичної теорії. 


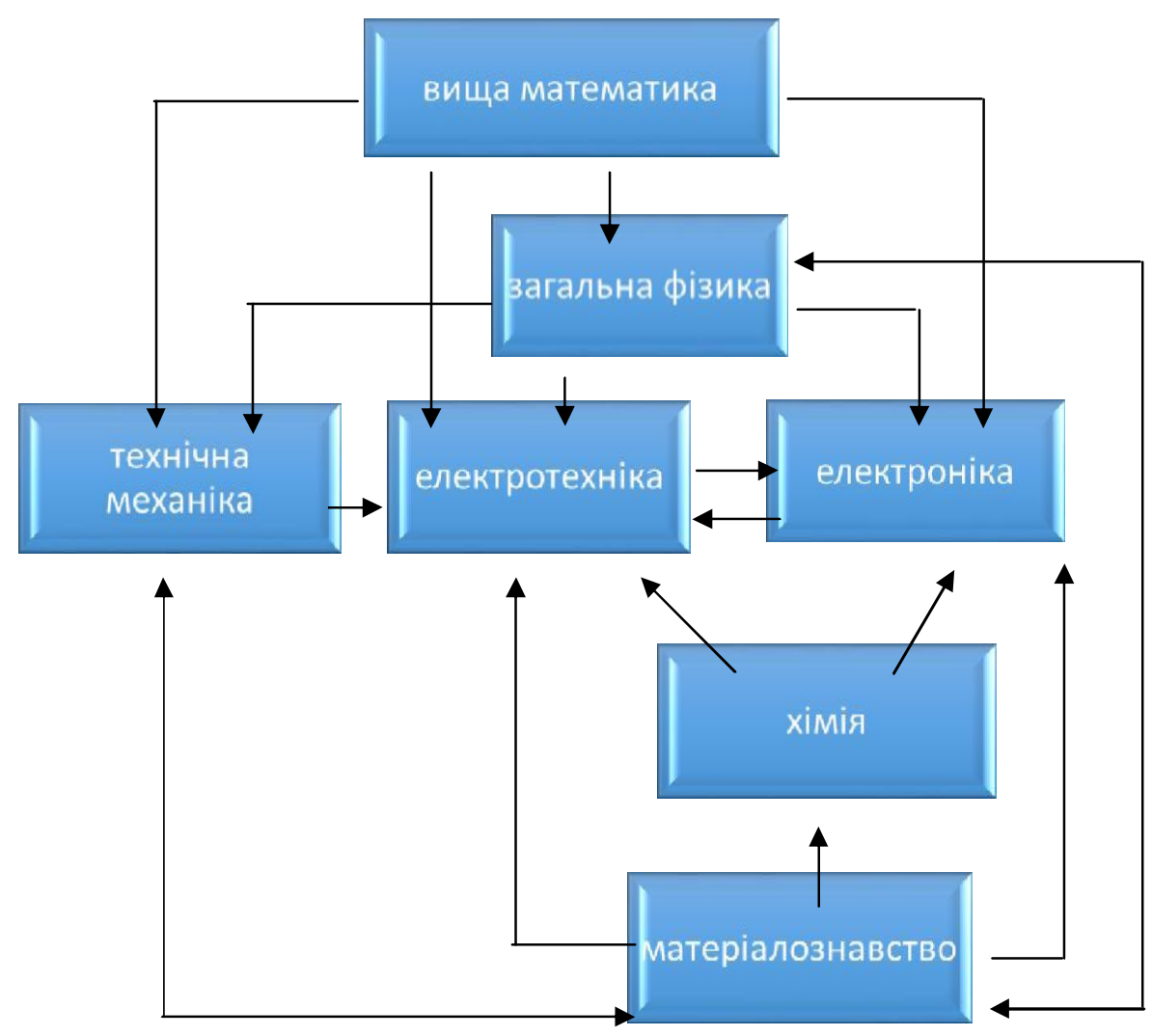

Рис. Схематичне зображення міждисциплінарних зв'язків

Існують тісні міждисциплінарні зв'язки курсу електротехніка та матеріалознавства. У матеріалознавстві вивчаються механічні властивості металів і сплавів, де студенти ознайомлюються з діаграмою розтягу металів, її основними точками й характеристиками міцності та пластичності. Також на сьогодні широкого вжитку набули аморфні метали або металічне скло,що входить у клас металевих твердих тіл з аморфною структурою, котра характеризується відсутністю далекого порядку й наявністю ближнього порядку у розташуванні атомів. На відміну від металів з кристалічною структурою, аморфні метали характеризуються фразовою однорідністю, їх атомна структура аналогічна структурі переохолоджених розплавів. Завдяки своїм магнітним властивостям, аморфні метали застосовуються в електротехніці та електроніці при виробництві магнітних екранів, зчитувальних головок пристроїв запису та зберігання інформації, трансформаторів. Мала залежність електричного опору від температури дає змогу використовувати їх як еталонні резистори.

Електротехніка та електроніка міцно пов'язані з вищою математикою, але не носить абстрактний характер. Тож викладачеві потрібно ненав язливо викликати зацікавлення до математики, наголошуючи, що велика спільність математичних понять і тверджень, які $€$ віддзеркаленням властивостей об'єктів та явищ реального світу, робить можливим успішне застосування математичних методів та висновків у вирішенні різних проблем науки і техніки. Наприклад, на практичних заняттях з вищої математики слід використовувати завдання, які розглядають розділи механіки, термодинаміки, електродинаміки, коливань, оптики, атомної 
фрізики. Це вказує на широке впровадження математичних знань при вирішенні прикладних задач із застосуванням усього різноманіття міждисциплінарних зв'язків. Однак можна зробити висновок, що подібні математичні завдання використовуються в курсі електротехніки та електроніки, і студенти повинні володіти методами їх розв'язання. Стає очевидним те, що підвищення якості навчання тягне за собою зміну ставлення студентів до математики за рахунок нових форм, методів і засобів організації навчального процесу і структурування матеріалу [7, с. 114]. Тому навчальні плани загальноінженерних дисциплін технічного спрямування повинні враховувати зміст та особливості математичного циклу. Так, "Електротехніка" базується на дисципліні "Електроніка" і курсі вищої математики. Без сумніву, виникає необхідність у створенні міждисциплінарних зв'язків, які б відповідали вимогам програми вищої професійної освіти і відображали логіку та специфріку і електротехніки, і математики, а, крім того, здатні були задовольнити потреби суміжних навчальних дисциплін. При реалізації міждисциплінарних зв'язків між цими дисциплінами необхідно відсіяти дублювання матеріалу, що досліджується. Разом з тим, вони повинні бути розраховані на реальне академічне навантаження у вищих закладах освіти і рівень підготовки студентів. Для досягнення цієї мети потрібен не лише щільний взаємозв'язок навчальних дисциплін, але і єдність методик, єдність фрорм подання та обробки інформації [8, с.34]. Особлива важливість встановлення міждисциплінарних зв'язків фундаментальних і загальноінженерних дисциплін потрібна в роботі при проведенні занять зі студентами стаціонарної форми навчання, при організації дистанційних фрорм навчання та при розробці комп'ютерних підручників. Навчальний курс “Електротехніка та електроніка" по праву займає чинне місце у впровадженні міждисциплінарних зв'язків, які спрямовані на розв'язання нестандартних рішень на сучасному етапі розвитку суспільства.

Висновки. Розглядаючи реалізацію міждисциплінарних зв'язків електротехніки та електроніки 3 фрізикою, математикою, хімією, матеріалознавством, можна зробити висновок, що їх об'єднує певна система понять. Як показує досвід, використання міждисциплінарних зв'язків стає ефективним у процесі навчання. Таким чином забезпечується висока якість знань, адже йде систематичне ознайомлення 3 цікавими науковими фрактами 3 інших дисциплін. А це сприяє цілеспрямованому і широкому розвитку творчих здібностей особистості. Життя у сучасному суспільстві вимагає істинних технічних знань, так що природничо-математичні дисципліни не можна вважати чимось другорядним в курсі "Електротехніка та електроніка". Викладання матеріалу набуває нових "відтінків" взаємопроникнення, адже містить звернення суміжних дисциплін, що створює нешаблонну атмосферу оригінальності, ініціативної розумової діяльності студентів. Електротехніка та електроніка,синтезуючи навколо себе інші дисципліни, створюють величезний міждисциплінарний потенціал,внаслідок чого діяльність викладача стає більш результативною, успішною, професійною.

Отже, у системі методичної роботи з упровадження міждисциплінарних зв'язків сконцентровано передову педагогічну думку, створено сприятливі умови для самоосвіти та самовдосконалення. 


\section{Використана література:}

1. Теоретичні основи електротехніки / В. С. Бойко, В. В. Бойко, Ю. Ф. Видолок та ін. Т. 1. Київ : ІВЦ”Видавництво “Політехніка", 2004. 272 с.

2. Малинівський С. М. Загальна електротехніка. Львів: Видавництво Національного ун-ту “Львівська політехніка", 2001. 594 с.

3. Гершунский Б. С. Образовательно-педагогическая прогностика. Теория, методология, практика : учебное пособие. Москва : Флинта: Наука, 2003. 768 с.

4. Абрамович В. Теоретичні аспекти міжпредметних зв'язків у шкільній освіті. Управління освітою. 2013. № 6. C. 21-25.

5. Капарнік Б. Міжпредметні зв’язки. Сутність поняття. Шкільний світ. 2012. № 6. С. $42-49$.

6. Коршак $\mathrm{C}_{\text {., }}$ Коршак Н. Математичне моделювання під час розв'язування фізичних задач. Фізика та астрономія в школі. 2010. № 3. С. 10-11.

7. Харченко М. Інтеграція міжпредметних зв'язків фізики та математики.

8. Харченко М. Міжпредметні зв'язки фізики і математики в процесі навчання у школі.

9. Осадчук Р. Педагогічні технології міжпредметних зв'язків у навчально-виховному процесі.

10. Бібік Г. В. Шляхи підвищення ефективності уроку математики: наук. пошук. Випуск наукових робіт. Херсон, 2004. С. 45-52.

11. Бевз В. Міжпредметні зв'язки як необхідний елемент предметної системи навчання. Математика в школі. 2003. № 6. С. 6-11.

\section{References:}

[1] Teoretychni osnovy elektrotekhniky / V. S. Boyko, V. V. Boyko, Yu. F. Vydolok. T. 1. Kyiv : IVTS "Vydavnytstvo "Politekhnica", 2004. 272 s.

[2] Malynivs`kyy S. M. (2003). Zahal'na elektrotekhnica. L'viv: Vydavnytstvo Natsional noho un-tu "L'vivs`ka politekhnica". $594 \mathrm{~s}$.

[3] Gershunskiy B. S. (2003). Obrazovatel no-pedagogicheskaya prognostika. Teoriya, metodologiya, praktika : uchebnoye posobiye. Moskva : Flinta: Nauka. $768 \mathrm{~s}$.

[4] Abramovych V. (2013). Teoretychni aspekty mizhpredmetnykh zvyazkiv u shkil'ni osviti. Upravlinya osvitou. № 6. S. 21-25.

[5] Kaparnik B. Mizhpredmetni zv`zky. Sutnist` ponyat`. Shkil`nyi svit. 2012. № 6. S. 42-49.

[6] Korshak E., Korshak N. (2010). Matematychne modeluvanya pid chas pozvyazuvanya fizychnykh zadach. Fizyka ta astronomiya u shkoli. № 3. S. 10-11.

[7] Kharchenko M. Integratsiya mizhpredmetnykh zvyazkiv fiziky ta matematyky.

[8] Kharchenko M. Mizhpredmetny zvyazky fiziky I matematyky v procesi navchanya u shkoli.

[9] Osadchuk R. Pedagogichni technologiy mizhpredmetnykh zvyazkiv u nvchal'no-vikhovnomu procesi.

[10] BibikG. V. (2004). Shlyakhy pidvishenya efektyvnosty uroky matematiky : nauk. poshuk. Vipusk naukovikh robit. Kherson. S. 45-52.

[11] Bevz V. (2003). Mishpredmetni zvyazky yak neobkhidnyi element predmetnoi systemy navchanya. Matematika u shkoli. № 6. S. 6-11.

\section{Дидык А. О. Реализация междисциплинарных связей в процессе обучения электротехники и электроники.}

Проблема реализации междисциплинарных связей в процессе изучения электротехники и электроники не потеряла свою актуальность и ныне. Это одно из наиболее сложных методических задач преподавателя, где он должен сконщентрировать знания по другим дисциплинам, соединив их в целостную систему.

B статье теоретически обоснована реализация междисииплинарных связей в преподавании электротехники и электроники в вузах. Определены место и роль курса общей физики, высшей математики, химии и технической механики в процессе изучения электротехники и электроники. Рассмотрен учебный курс “Электротехника и электроника", который имеет важное значение при внедрении междисииплинарных связей, которые направлены на решение нестандартных решений на современном этапе развития общества. Электротехника и электроника, синтезируя вокруг себя другие дисииплины, создают огромный междисииплинарный потенциал, в результате чего деятельность преподавателя становится 
более результативной, успешной, профессиональной. Конкретизировань учебные темь этих курсов, на базе которых основанно изучение электротехники и электроники. Продемонстрированы пути корректирования учебной программы с учетом содержания этих курсов, которые устраняют дублирование и повторы.

Установление междисциплинарных связей между преподаванием курса электротехники, электроники, физики, химии, технической механики, высшей математики способствует более углубленному усвоению знаний, научных понятий и законов, усовериенствованию учебновоспитательного прочесса и оптимальной его организации, формированию научного мировоззрения, единства материального мира, взаимосвязи явлений в природе и обществе. Реализация меэндисциплинарных связей отстраняет дублирование в изучени материала, экономит время и создает благоприятные условия для формирования профессиональных компетентностей.

Ключевые слова: междисциплинарные связи, электротехника, электроника, физика, химия, математика, материаловедение.

DIDYK A. O. Implementation of interdisciplinary connections in the process of teaching Electrical Engineering and Electronics.

The problem of interdisciplinary communication in the study of electrical engineering and electronics has not lost its relevance today. This is one of the most complex methodical tasks of the teacher, where he must concentrate knowledge from other disciplines, combining them into a coherent system.

The article substantiates the theoretical substantiation of the implementation of interdisciplinary connections in the teaching of electrical engineering and electronics in universities. The role of Physics, higher mathematics, chemistry and technical mechanics in the process of learning Electrical Engineering and Electronics has been substantiated. The educational topics of this course have been specified, on the basis of which basic study of electrical engineering and electronics. The ways of adjusting the curriculum have been shown, taking into account the content of this section in order to eliminate duplication and repetition.

Establishing interdisciplinary links between teaching electrical engineering, electronics, physics, chemistry, technical mechanics, higher mathematics contributes to a more in-depth assimilation of knowledge, scientific concepts and laws, improving the educational process and its optimum organization, formation, worldview interconnection of phenomena in nature and society. The implementation of interdisciplinary relationships eliminates duplication in the study of the material, saves time and creates favorable conditions for the formation of professional competencies.

Keywords: interdisciplinary connections, Electrical Engineering, Electronics, Physics, Chemistry, Mathematics, Materials Science.

DOI: https://doi.org/10.31392/NZ-npu-143.2019.11

УДК 378

ORCID 0000-0002-7900-9424

Казаннікова О. В.

\section{PIBEHЬ СФОРМОВАНОСТІ ПРОФЕСІЙНОÏ КОМПЕТЕНТНОСТІ МАЙБУТНІХ СОЦІАЛЬНИХ ПЕДАГОГІВ У ПРОЦЕСІ ВИРОБНИЧОЇ ПРАКТИКИ}

У статті висвітлюється актуальність формування професійної компетентності майбутніх сочіальних педагогів у прочесі виробничої практики в умовах реформування української освітньої системи та активного насичення ії гуманістичними иінностями.

Виокремлено структурні компоненти професійної компетентності та обгрунтовано 